\title{
HSPB1 wt Allele
}

National Cancer Institute

\section{Source}

National Cancer Institute. HSPB1 wt Allele. NCI Thesaurus. Code C49548.

Human HSPB1 wild-type allele is located in the vicinity of $7 q 11.23$ and is approximately 2

$\mathrm{kb}$ in length. This allele, which encodes heat-shock protein beta-1 protein, is involved in stress resistance responses. 